\title{
PENINGKATAN EFEKTIVITAS PENGELOLAAN SEKOLAH MELALUI PENGUATAN KEMAMPUAN MANAJERIAL KEPALA SEKOLAH
}

\author{
Nur Agus Salim \\ Universitas Mulawarman Samarinda \\ J1. Kuaro, Gunung Kelua, Samarinda Ulu, Gn. Kelua, Samarinda Ulu, \\ Kota Samarinda, Kalimantan Timur 75119 \\ Email: nuragussalim@uwgm.ac.id
}

\begin{abstract}
The purpose of this study is to find out how much influence the principal's managerial ability to improve the effectiveness of school management. The research method used is quantitative approach. Data collection techniques used questionnaires and data analysis techniques using descriptive and inferential statistics. Checking the validity of the data using the validity and reliability of the instruments to be used in the study. From result of hypothesis test that there is a significant and positive influence between managerial ability to effectiveness of school management with result of test of $F=430.332$ and $t$ test $=20.744$ with significance value 0,000 . The contribution of managerial ability to the effectiveness variable of school management is 0,606 which can be interpreted that $60,6 \%$ variance of school management effectivity can be influenced by managerial ability variable and the rest influenced by other variable not examined in this research. Based on these results it can be concluded that the increased effectiveness of management can be done by strengthening the principal's managerial ability.
\end{abstract}

Keywords: effectiveness of school management, managerial ability.

\begin{abstract}
Abstrak: Tujuan dari penelitian ini adalah untuk mengetahui seberapa besar pengaruh kemampuan manajerial kepala sekolah terhadap peningkatan efektivitas pengelolaan sekolah. Metode penelitian yang digunakan yaitu pendekatan kuantitatif. Teknik pengumpulan data menggunakan kuesioner dan teknik analisis data dengan menggunakan statistik deskriftif dan inferensial.Pengecekan keabsahan data menggunakan validitas dan realibilitas instrumen yang akan digunakan dalam penelitian. Dari hasil uji hipotesisterdapat pengaruh yang signifikan dan positif antara kemampuan manajerial terhadap efektivitas pengelolaan sekolah dengan hasil uji $\mathrm{F}=430.332$ dan uji $\mathrm{t}=20.744$ dengan nilai signifikansi 0,000 . Kontribusi kemampuan manajerial terhadap variabel efektivitas pengelolaan sekolah adalah 0,606 yang dapat diinterpretasikan bahwa sebesar $60,6 \%$ varian efektivitas pengelolaan sekolah dapat dipengaruhi oleh variabel kemampuan manajerial dan sisanya dipengaruhi variabel lain yang tidak diteliti dalam penelitian ini. Berdasarkan hasil tersebut maka dapat disimpulkan bahwa peningkatan efektivitas pengelolaan dapat dilakukan dengan penguatan kemampuan manajerial kepala sekolah.
\end{abstract}

Kata Kunci: efektivitas pengelolaan sekolah, kemampuan manajerial.

Prestasi sekolah yang baik diperlukan pengelolaan sekolah yang baik. Pengelolaan sekolah yang baik dibutuhkan suatu standar khusus agar terjadi pemerataan di tiap sekolah/madrasah. Standar Pengelolaan Pendidikan diatur dalam Peraturan Menteri Pendidikan Nasional Nomor 19 tahun 2007. Peraturan Menteri tersebut terdapat hal-hal yang harus diperhatikan dalam pen- gelolaan pendidikan di antaranya,perencanaan program, pelaksanaan rencana kerja, pengawasan dan evaluasi, kepemimpinan sekolah/madrasah, sistem informasi manajemen, dan penilaian khusus. Tertuang pula dalam Peraturan Pemerintah Nomor 19 Tahun 2005 tentang Standar Nasional Pendidikan Pasal 49 s/d 58 yang mengatur tentang standar pengelolaan pendidikan oleh satuan 
pendidikan yang berkaitan dengan perencanaan, pelaksanaan, dan pengawasan kegiatan pendidikan pada tingkat satuan pendidikan agar tercapai efisiensi dan efektivitas penyelenggaraan pendidikan.

Pemerintah dengan kebijakan dan tanggungjawabnya selalu berupaya meningkatkan dan mengembangkan pendidikan khususnya pendidikan dasar. Salah satu upaya peningkatan tersebut tertuang dalam Undang-Undang Republik Indonesia Nomor 23 tahun 2014 tentang Pemerintahan Daerah bahwa tanggung jawab pendidikan setingkat SD/SMP berada dalam lingkup pemerintah kabupaten/kota sedangkan Pemerintah Provinsi bertanggung jawab atas pendidikan setingkat SMA/SMK dan Pemerintah Pusat bertanggung jawab atas pendidikan tinggi. Undang-undang ini dilaksanakan penuh per 1 Januari 2017. Ini merupakan upaya nyata pemerintah dalam pengelolaan pendidikan dasar yang salah satunya adalah sekolah dasar. Dengan diberlakukannya undang-undang tersebut maka pemerintah daerah tingkat II dapat berkonsentrasi penuh dalam peningkatan mutu pendidikan dasar yang meliputi kewenangan-kewenangan menyangkut alokasi danadari APBN dan APBD, tenaga pengajar, infrastruktur sekolah, pembangunan sekolah, dan siswa.

Peningkatan kualitas sumber daya manusia melalui pendidikan belum mencapai mutu atau kualitas yang kompetitif. Kebijakan otonomi daerah telah menghasilkan perubahan dalam pengelolaan permasalahan pendidikan. Dengan otonomi pengelolaan melalui manajemen berbasis sekolah sebagian besar keputusan pendidikan harus dibuat ditingkat sekolah. Otonomi pengelolaan ini mengikutsertakan peran stake holder atau yang berkepentingan terhadap pendidikan untuk ikut serta mempengaruhi keberhasilan sekolah. Kenyataan di lapangan menurut kajian Mustiningsih (2015) bahwa permasalahan secara umum yang ditemukan dalam implementasi MBS di sekolah dasar adalah meliputi implementasi: (1) manajemen kurikulum dan pembelajaran berbasis sekolah, (2) manajemen peserta didik berbasis sekolah; (3) manajemen pendidik dan tenaga kependidikan berbasis sekolah; (4) manajemen sarana dan prasarana berbasis sekolah; (5) manajemen pembiayaan berbasis sekolah; (6) manajemen humas berbasis sekolah; dan (7) manajemen budaya dan lingkungan berbasis sekolah.

Melihat realita dan fakta tersebut maka perlu motivasi kuat bagi pengelola, pendidik dan tenaga kependidikan sekolah dasar untuk mengelola sekolah menjadi efektif untuk menjadikannya sebuah lembaga yang potensial. Kuncinya tentu saja pengelolaan sekolah yang efektif yang menjunjung pengabdian serta mengarah profesionalisme baik dalam pengadaan sarana, penerapan metode pembelajaran dan kurikulum serta rekruitmen tenaga pendidik dan kependidikan. Siagian (2002:20) mengatakan bahwa efektivitas adalah pemanfaatan sumber daya, dana, sarana dan prasarana dalam jumlah tertentu yang secara sadar ditetapkan sebelumnya untuk menghasilkan sejumlah barang dengan mutu tertentu tepat pada waktunya. Berarti efektivitas sebagai orientasi kerja menyoroti empat hal, yaitu: (1) sumber daya, dana, sarana dan prasarana yang dapat digunakan sudah ditentukan dan dibatasi, (2) jumlah dan mutu barang atau jasa yang harus dihasilkan telah ditentukan, (3) batas waktu untuk menghasilkan barang atau jasa tersebut sudah ditetapkan, dan (4) tata cara yang harus ditempuh untuk menyelesaikan tugas sudah dirumuskan. Dengan demikian maka dalam efektivitas sekolah memvalidasi paradigma pengembangan model dengan memberikan kekuasaan sekolah untuk menerapkan keputusan, kebijakan, dan arah pengorganisasian yang bertumpu pada kekuasaan anggaran, sarana, dan personel pengelolaannya. Dalam manajemen sekolah ada lima efektivitas yang perlu dikembangkan, yaitu: (1) prinsip kepemimpinan yang mantap; (2) harapan yang tinggi dari penampilan siswa; (3) mengutamakan dasar kecakapan; (4) penugasan dan pengawasan yang tepat; dan (5) tingkat evaluasi penampilan siswa. Scheerens (2003:42) memberikan analisa tentang faktor-faktor yang dapat meningkatkan efektivitas yaitu: (1) prestasi, orientasi, harapan tinggi, (2) kepemimpinan pendidikan, (3) konsensus dan kohesi antar staf, (4) kualitas kurikulum/kesempatan belajar, (5) iklim sekolah, (6) potensi evaluatif, (7) keterlibatan orang tua, (8) iklim kelas, dan (9) waktu belajar efektif.

Berdasarkan kenyataan tersebut di atas, perlu dilakukan upaya-upaya perbaikan, salah satunya adalah melakukan reorientasi penyelenggaraan pendidikan. Misalnya tidak diperlukannya lagi intervensi pemerintah pusat 
ke daerah atau ke sekolah. Hal ini dimaksudkan supaya otonomi sekolah untuk menentukan sendiri apa yang perlu dilakukan dalam kegiatan belajar mengajar dan mengelola sumber daya yang ada untuk berinovasi semakin meningkat. Sedangkan partisipasi masyarakat ditampakkan pada tingginya keterlibatan mereka sehingga setiap unsur dapat berperan dalam meningkatkan kualitas, efisiensi, dan pemerataan kesempatan, pendidikan dengan memodifikasi struktur pengambilan keputusan dari pemerintah pusat ke daerah dan seterusnya ke sekolah.

Berangkat dari hal yang telah disebutkan di atas maka dalam pengelolaan sekolah sangat diperlukan orang yang benar-benar mapan dalam bidangnya terutama dalam pengelolaan sekolah yang efektif. Dibutuhkan kepala sekolah yang berkualitas dan memiliki dedikasi sehingga tepat dalam pengambilan kebijakan atau keputusan dalam upaya mewujudkan pengelolaan sekolah yang efektif. Untuk melaksanakan hal tersebut diperlukan kepala sekolah yang berkualitas yang memiliki IPTEK, IMTAQ, keterampilan dan pengalaman serta profesional di bidang pengelolaan sekolah yang efektif dan efisien. Menjadikan sekolah yang efektif perlu adanya seorang pemimpin yang kuat karena makna kepemimpinan adalah sikap seseorang untuk dapat mempengaruhi orang lain agar dapat bekerja sesuai tanggung jawab dan dapat mencapai tujuan yang diinginkan. Kualitas kepemimpinan sangat mempengaruhi tercapainya sekolah efektif. Kepalah sekolah dalam hal ini sebagai pemimpin formal dan faktual sebuah sekolah harus mampu untuk mengkolaborasi dan mensinergikan komponen-komponen sekolah seperti guru, murid, dan karyawan sekolah yang lain. Selain itu, kepala sekolah juga harus mampu memaksimalkan sarana prasarana yang sudah ada di sekolah yang dipimpinnya.

Kepala sekolah sudah semestinya mampu menjadi contoh integritas yang patut dicontoh oleh guru dan murid yang ada di sekolah. Integritas seorang pemimpin sangat mempengaruhi kualitas kepemimpinan seseorang, dengan integritas yang baik, seorang pemimpin dalam hal ini kepala sekolah akan ditaati dan dihormati oleh guru dan siswa yang dipimpinnya, sehingga dapat tercipta lingkungan organisasi sekolah yang tertib dan kondusif. Kepala sekolah juga sudah selayaknya untuk fokus dalam mengawasi apa yang terjadi di dalam kelas sebagai inti dari baik tidaknya pendidikan di dalam sekolah. Keberlansungan pengawasan kelas ini sangat penting untuk menjaga kualitas kegiatan belajar mengajar di sekolah tersebut. Saat proses dirasa tidak sesuai dengan standar, maka kepala sekolah beserta guru dan tenaga pendidik yang ada di sekolah akan bekerja sama untuk mengusahakan perbaikan sehingga kualitas pelayanan terhadap siswa akan berjalan maksimal. Namun kenyataan di lapangan sebagaimana dikutip penulis dari harian Media Indonesia bahwa hanya 10\% kepala sekolah yang sudah tersertifikasi padahal menurut Permendiknas nomor 13/2007 tentang standar kompetensi kepala sekolah, seorang kepala sekolah mesti besertifikat kepala sekolah, baik itu kepsek SD/MI, SMP/MS, maupun SMA/ MA. Permasalahan lain adalah pengangkatan kepala sekolah yang masih terkait politik daerah sehingga banyak yang belum sesuai dengan mekanisme yang ada.

\section{METODE PENELITIAN}

Penelitian ini dilakukan pada SD Negeri yang tersebar pada 3 Kecamatan di Kabupaten Kutai Karetanegara Provinsi Kalimantan Timur yakni kecamatan Samboja, Muara Jawa dan kecamatan Sanga-sanga. Alasan memilih ketiga kecamatan ini adalah karena kecamatan Samboja, Muara Jawa dan Sanga-sanga merupakan kecamatan yang memiliki pendapatan asli daerah yang cukup besar dan jumlah sekolah serta tenaga pengajar yang banyak sehingga perlunya penelitian ini dilakukan guna mengetahui bagaimanakah pengelolaan sekolah dasarnya serta dikarenakan belum adanya penelitian yang dilakukan mengenai pengelolaan sekolah di ketiga kecamatan tersebut selama ini.Penelitian dilaksanakan selama enam bulan, dimulai pada bulan Januari 2017 sampai dengan Juni 2017. Pada bulan Januari 2017 dilaksanakan pengurusan izin penelitian, ujicoba instrumen, kalibrasi, dan penyempurnaan instrumen. Pada bulan Februari 2017s/d Juni 2017 dilaksanakan pengambilan data, analisis data, dan penulisan seminar hasil penelitian.

Dalam penelitian ini metode yang dipakai adalah metode penelitian kuantitaf. Metode ini digunakan untuk mengetahui adanya pengaruh kemampuan manajerial kepala sekolah, kompen- 
sasi, manajemen konflik, dan pengambilan keputusan terhadap efektivitas pengelolaan sekolah pada sekolah dasar negeri di Kabupaten Kutai Kartanegara. Penulis akan mencari pengaruh kemampuan manajerial kepala sekolah terhadap efektivitas pengelolaan sekolah namun sebelum penulis mengambil data terlebih dahulu penulis akan melakukan uji coba instrumen untuk menguji validitas dan reabilitasnya. Setelah penganalisaan instrumen dilakukan kemudian dilakukan pengumpulan data dengan menggunakan instrumen yang valid dari hasil uji validitas dan reabilitas tersebut.

Populasi dalam penelitian ini adalah pengajar pada SD Negeri di Kecamatan Samboja, Muara Jawa dan Sanga-sanga. Jumlah populasinya adalah seluruh pengajar pada SD Negeri yang tersebar di wilayah zona 5 Kabupaten Kutai Kartanegara Provinsi Kalimantan Timur dengan rincian pada tabel 1 berikut:

Tabel 1 Populasi Penelitian

\begin{tabular}{cccc}
\hline No & Kecamatan & $\begin{array}{c}\text { Jumlah } \\
\text { Sekolah }\end{array}$ & $\begin{array}{c}\text { Jumlah } \\
\text { Pendidik }\end{array}$ \\
\hline 1 & Samboja & 40 & 449 \\
2 & Muara Jawa & 18 & 298 \\
3 & Sanga-sanga & 15 & 208 \\
\hline & Total & 73 & 955 \\
\hline
\end{tabular}

Teknik pemilihan sampel yang digunakan adalah sampel yang diambil kurang proporsional karena responden dengan pendidikan D3, S1 dan S2 tidak seimbang sehingga untuk responden dengan pendidikan D3 dan S2 akan diambil seluruhnya karena jumlahnya sangat sedikit. (Disproportionate Startified Random Sampling). Teknik pengumpulan data dilakukan denganmenggunakan instrumen penelitian berbentuk kuesioner. Namun sebelum intstrumen digunakan untuk penelitian Instrumen akandiuji coba terlebih dahulu pada pengajar yang bukan menjadi responden penelitian yang berjumlah 30 guru. Pengujian instrumen tersebut meliputi uji keabsahan (validity) dan uji keandalan (reliability). Dari hasil pengujian tersebut diperoleh butir-butir instrumen yang valid dan tidak valid. Adapun instrumen yang tidak valid dibuang.Suatu penelitian membutuhkan analisis data dan interpretasinya yang bertujuan menjawab setiap pertanyaan peneliti dalam rangka mengungkap fenomena sosial tertentu. Analisis data adalah proses penyederhanaan data ke dalam bentuk yang lebih mudah dibaca dan diinterpretasikan. Metode yang dipilih untuk menganalisis data harus sesuai dengan pola penelitian dan variabel yang diteliti.

Analisisdatayang digunakan dalampenelitian ada dua bagian yaitu deskriptif dan analisis inferensial. Analisis data deskriptif yaitu statistik yang digunakan untuk menganalisis data dengan cara mendiskripsikan atau menggambarkan data yang terkumpul sebagaimana apa adanya tanpa bermaksud membuat kesimpulan yang berlaku untuk umum atau generalisasi. Menurut Sugiyono (2013:208) analisis deskriptif bertujuan untuk memperoleh gambaran karakteristik penyebaran skor setiap variabel penelitian dengan menghitung rata-rata, simpang baku, median, dan modus. Sedangkan statistik inferensial yaitu statistik yang menganalisa data, sampel dan hasilnya diberlakukan untuk populasi. Sebelum dilakukan pengujian hipotesis, terlebih dahulu dilakukan pengujian persyaratan analisis yang terdiri dari uji normalitas dan uji homogenitas. Untuk efisiensi pengolahan data maka analisis deskriptif dan analisis inferensial baik untuk uji normalitas, menguji hipotesis pertama, menguji hipotesis kedua, dan menguji hipotesis ketiga menggunakan bantuan program komputer yaitu mengola data dalam program SPSS versi 16.0

\section{HASIL}

\section{Efektivitas Pengelolaan Sekolah Dasar}

Data hasil penelitian tentang variabel efektivitas pengelolaan sekolah dasar di Kabupaten Kutai Kartanegara yang dijaring melalui angket sebanyak 282 orang guru. Angket efektivitas pengelolaan sekolah mengukur kemampuan sekolah dalam melaksanakan tugas dan fungsinya dalam mencapai keberhasilan programsesuai dengan tujuan yang sudah ditentukan. Angket ini berupa pernyataan yang berjumlah 22 item dengan menggunakan skor penilaian skala Likert 1 sampai dengan 5 .

Ada 282 data yang berhasil terkumpul dan tidak ada data yang dihapus. Dari data tersebut nampak rentang skor atau jangkauan efektivitas pengelolaan SD di Kabupaten Kutai Kartanegara sebesar 53 yaitu skor terendah 55 dan skor tertinggi 108. Diperoleh ukuran pemusatan data yaitu mean (rata-rata) dengan skor sebesar 89,18 jika dibandingkan rerata skor ideal yaitu 55 maka 
rerata efektivitas pengelolaan sekolah masih di atas rerata skor ideal. Dengan demikian dapat mencerminkan bahwa efektivitas pengelolaan SD di Kabupaten Kutai Kartanegara dapat dikatakan baik, dan nilai rerata/mean sebesar 89,18 hampir sama dengan skor nilai median sebesar 91,00. Hal ini menunjukkan bahwa kebanyakan skor efektivitas pengelolaan SD di Kabupaten Kutai Kartanegara hampir seimbang antara skor yang berada di atas maupun di bawah skor rata-rata. Sedangkan nilai yang sering muncul (modus) adalah 91 hal ini berarti pada distribusi normal subyek banyak yang memilih atau memperoleh skor 91.

Berdasarkan hasil analisis diskriptif diperoleh rerata $($ mean $)=89,18$ dan 1 standar deviasi $(\mathrm{SD})=$ 9.386. Kategori Tinggi bila $89,18+9,368=$ 98,566 dibulatkan menjadi 99. Kategori rendah $89,18+9,368=79,794$ dibulatkan menjadi 80 . Sedangkan Kategori sedang antara 81 dan 98. Untuk lebih jelasnya dapat dilihat pada tabel 2 berikut ini:

Tabel 2 Kategori Skor Efektivitas pengelolaanSekolah Dasar di Kabupaten Kutai Kartanegara

\begin{tabular}{ccccc}
\hline No & Kategori & Skor & Frekuensi & Persentasi \\
\hline 1 & Rendah & $\leq 80$ & 46 & $16 \%$ \\
2 & Sedang & $81-98$ & 194 & $69 \%$ \\
3 & Baik & $\geq 99$ & 42 & $15 \%$ \\
& Jumlah & & 282 & $100 \%$ \\
\hline
\end{tabular}

Sumber: Hasil Penelitian

Dari tabel 2 di atas dapat di ketahui bahwa efektivitas pengelolaan SD di Kabupaten Kutai Kartanegara yang memiliki kategori rendah sebanyak 46 orang dengan persentasi sebesar $16 \%$, Kategori sedang sebanyak 194 orang dengan persentasi $69 \%$. Sedangkan efektivitas pengelolaan sekolah yang mempunyai kategori baik sebanyak 42 orang dengan persentasi $15 \%$. Dengan demikian dapat dikatakan bahwa efektivitas pengelolaan SD di Kabupaten Kutai Kartanegarasebagian besar mempunyai kategori sedang dan sebagian lagi memiliki kategori rendah dan tinggi.

\section{Kemampuan Manajerial Kepala Sekolah}

Data hasil penelitian tentang variabel Kemampuan manajerial SD di Kabupaten Kutai Kartanegara yang dijaring melalui angket sebanyak 282 orang guru. Angket Kemampuan manajerial yang mengungkap tentang kapasitas yang dimiliki oleh seorang kepala sekolah dalam mengelola organisasi dan sumber daya yang ada dalam mencapai tujuan organisasi secara efesien dan efektif. Angket ini berupa pernyataan yang berjumlah 20 item dengan menggunakan skor penilaian skala likert 1 sampai dengan 5 .

Ada 282 data yang berhasil terkumpul dan tidak ada data yang dihapus. Dari data tersebut nampak rentang skor atau jangkauan kemampuan manajerial kepala SDN di Kabupaten Kutai Kartanegara sebesar 50 yaitu skor terendah 50 dan skor tertinggi 100. Rerata skor (mean) sebesar 83,82 jika dibandingkan rerata skor ideal yaitu 50 maka rerata kemampuan manajerial masih di atas rerata skor ideal. Dengan demikian dapat mencerminkan bahwa kemampuan manajerial kepala SDN di Kabupaten Kutai Kartanegara dapat dikatakan baik. Dan nilai rerata/ mean sebesar 83,82 berada mendekati skor nilai median sebesar 84,00. Hal ini menunjukkan bahwa kebanyakan skor kemampuan manajerial kepala SDN di Kabupaten Kutai Kartanegara hampir seimbang antara skor yang berada di atas maupun di bawah skor rata-rata.

Berdasarkan hasil analisis diskriptif diperoleh rerata $($ mean $)=83,82$ dan 1 standar deviasi $(\mathrm{SD})=$ 9,659. Kategori Tinggi bila $83,82+9,659=$ 93,479 dibulatkanmenjadi 93. Kategori rendah $82,82-9,659=74,161$ dibulatkan menjadi 74 . Sedangkan Kategori sedang antara 75 dan 92. Untuk lebih jelasnya dapat dilihat pada tabel 3 berikut ini:

Tabel 3 Kategori Skor Kemampuan Manajerial KepalaSDN di Kabupaten Kutai Kartanegara

\begin{tabular}{ccccc}
\hline No & Kategori & Skor & $\begin{array}{c}\text { Fre- } \\
\text { kuensi }\end{array}$ & Persentasi \\
\hline 1 & Rendah & $\leq 74$ & 40 & $14 \%$ \\
2 & Sedang & $55-92$ & 199 & $71 \%$ \\
3 & Baik & $\geq 93$ & 43 & $15 \%$ \\
\hline & Jumlah & & 282 & $100 \%$ \\
\hline
\end{tabular}

Sumber: Hasil Penelitian

Dari tabel 3 tersebut dapat di ketahui bahwa kemampuan manajerial kepala SDN di Kabupaten Kutai Kartanegarayang memiliki kategori rendah sebanyak 40 orang dengan persentasi sebesar 14\%, Kategori sedang sebanyak 199 orang dengan persentasi $71 \%$. Sedangkan kemampuan manajerial yang mempunyai kategori baik sebanyak 15 orang 
dengan persentasi $15 \%$. Dengan demikian dapat dikatakan bahwa kemampuan manajerial Kepala SDN di Kabupaten Kutai Kartanegara sebagian besar mempunyai kategori sedang dan sebagian lagi memiliki kategori rendah dan tinggi.

Hasil perhitungan analisis regresi uji signifikansi persamaan garis regresi sederhana dan linieritas antara variabel kemampuan kepala sekolah (X1) dengan efektivitas pengelolaan sekolah (Y) menghasilkan arah regresi (b) sebesar 0,756 dan konstanta (a) sebesar 25,783. Dengan demikian bentuk persamaan linier kedua variabel tersebut dapat digambarkan sebagai berikut $\hat{Y}=25,783+0,756 \mathrm{X} 1$.

Selanjutnya untuk mengetahui derajat keberartian persamaan regresi dilakukan dengan uji F. Persyaratan hipotesis apabila $\mathrm{Sig}<\alpha=0,05$. Berdasarkan hasil perhitungan uji signifikansi regresi seperti tampak pada tabel 4.16 diperoleh nilai Sig $=0,000$. Apabila nilai sig di bandingkan dengan nilaia, maka $0,000<0,05$. Hal ini menunjukkan bahwa pengaruh antara variabel kemampuan manajerial (X1) dengan variabel efektivitas pengelolaan sekolah (Y) adalah positif dan signifikan. Selengkapnya hasil perhitungan uji signifikansi dan nilai koefisien regreasi antara variabel kemampuan manajerial (X1) dengan variabel efektivitas pengelolaan sekolah $(\mathrm{Y})$ dapat dilihat pada tabel 4 di berikut ini.

Berdasarkan hasil uji $F$ pada tabel 4 diperoleh Fhitung 430,332> 3,875 Ftabel dengan sig $=0,000<5 \%$ ini berarti model regresi linier

Tabel 4Analisis Varians Uji Signifikansi Persamaan Regresi X1 Terhadap Y

\begin{tabular}{ccccccc}
\hline & Model & Sum of Squares & Df & $\begin{array}{c}\text { Mean } \\
\text { Square }\end{array}$ & F & Sig. \\
\hline 1 & Regression & $\mathbf{1 4 9 9 7 . 1 1 2}$ & $\mathbf{1}$ & $\mathbf{1 4 9 9 7 . 1 1 2}$ & $\mathbf{4 3 0 . 3 3 2}$ & $\mathbf{. 0 0 0 a}$ \\
& Residual & $\mathbf{9 7 5 8 . 0 2 3}$ & $\mathbf{2 8 0}$ & $\mathbf{3 4 . 8 5 0}$ & & \\
\hline Total & $\mathbf{2 4 7 5 5 . 1 3 5}$ & $\mathbf{2 8 1}$ & & & \\
\hline
\end{tabular}

Tabel 5 Hasil Uji t Persamaan Regresi X1 Terhadap Y

\begin{tabular}{|c|c|c|c|c|c|c|}
\hline \multicolumn{7}{|c|}{ Coefficientsa } \\
\hline & \multirow[t]{2}{*}{ Model } & \multicolumn{2}{|c|}{ Unstandardized Coefficients } & \multirow{2}{*}{$\begin{array}{c}\text { Standardized } \\
\text { Coefficients }\end{array}$} & \multirow[t]{2}{*}{$\mathbf{t}$} & \multirow[t]{2}{*}{ Sig. } \\
\hline & & B & Std. Error & & & \\
\hline \multirow[t]{2}{*}{1} & (Constant) & 25.783 & 3.076 & & 8.382 & .000 \\
\hline & Manajerial & .756 & .036 & .778 & 20.744 & .000 \\
\hline
\end{tabular}

dapat digunakan untuk memprediksi pengaruh kemampuan manajerial terhadap efektivitas pengelolaan sekolah.Sedangkan untuk menguji signifikansi koefisien parameter regresi antara variabel kemampuan manajerial (X1) dengan variabel efektivitas pengelolaan sekolah (Y) hipotesis yang digunakan Ho yang menyebutkan bahwa variabel kemampuan manajerial tidak mempengaruhi variabel efektivitas pengelolaan sekolah dan hipotesis alternatif (H1) menyebutkan bahwa variabel kemampuan manajerial (X1) mempengaruhi variabel efektivitas pengelolaan sekolah (Y) dengan melakukan pengujian hipotesis secara parsial (uji t). Hasil perhitungan dapat dilihat pada tabel 5 berikut ini.

Berdasarkan hasil perhitungan diperoleh nilai thitung $=20.744>1,969$ ttabel dan dengan sig $=0,000<5 \%$ maka H0 ditolak. Ini berarti variabel kemampuan manajerial secara statistik berpengaruh signifikan terhadap variabel dependen efektivitas pengelolaan sekolah. Maka secara parsial variabel kemampuan manajerial (X1) mempengaruhi variabel efektivitas pengelolaan sekolah (Y). Dengan demikian dapat disimpulkan bahwa persamaan regresi. $\hat{\mathrm{Y}}=25,783+0,756 \mathrm{X} 1$ dikatakan pengaruhnya signifikan. Persamaan regresi tersebut dapat diinterpretasikan jika kemampuan manajerial $=$ 0 maka efektivitas pengelolaan sekolah sebesar 25,783 dan jika variabel kemampuan manajerial mangalami kenaikan satu poin maka akan menyebabkan kenaikan pada variabel efektivitas pengelolaan sekolah sebesar 0,756 . 
Uji determinasi digunakan untuk melihat seberapa besar pengaruh variabel independen terhadap variabel dependen. Nilai koefisien determinasi antara kemampuan manajerial dengan variabel efektivitas pengelolaan sekolah adalah ryx $12=0,606$, hal ini berarti bahwa $60,6 \%$ varians efektivitas pengelolaan sekolah dapat dipengaruhi oleh kemampuan manajerial dan sisanya dipengaruhi oleh variabel lain yang tidak berhasil diteliti.

\section{PEMBAHASAN}

Hasil uji hipotesis menunjukkan bahwa terdapat pengaruh yang signifikan dan positif antara kemampuan manajerial terhadap efektivitas pengelolaan sekolah. Maka semakin baik kemampuan manajerial, cenderung akan semakin tinggi pula efektivitas pengelolaan sekolah tersebut. Sebaliknya, semakin rendah kemampuan manajerial, cenderung semakin rendah pula efektivitas pengelolaan sekolah tersebut. Kemampuan manajerial dalam rangka meningkatkan efektivitas pengelolaan sekolah jelas sangat berpengaruh. Kemampuan manajerial memiliki kontribusi yang sangat kuat terhadap efektivitas pengelolaan sekolah.

Dari hasil analisis tersebut membuktikan hipotesis penelitian yang menduga ada pengaruh antara kemampuan manajerial terhadap efektivitas pengelolaan SDN di Kabupaten Kutai Kartanegara. Hasil penelitian dan pengujian hipotesis pengaruh antara kemampuan manajerial terhadap efektivitas pengelolaan sekolah memberikan makna bahwa faktor kemampuan manajerial seperti menyusun perencanaan sekolah, pengembangan organisasi, pengelolaan sekolah, menciptakan budaya dan iklim sekolah, pengelolaan kurikulu, pengelolaan keuangan, pengelolaan sistem informasi dan evaluasi terbukti mampu memberikan kontribusi yang signifikan terhadap efektivitas pengelolaan sekolah dasar negeri di Kabupaten Kutai Kartanegara.

Berdasarkan Penelitian sebelumnya yang dilakukan oleh Akdon tentang Identifikasi faktorfaktor kemampuan manajerial yang diperlukan dalam implementasi School Based Management dan implikasinya terhadap prgram pembinaan kepala sekolah. Dari hasil penelitan tersebut menyebutkan bahwa kemampuan manajerial adalah seperangkat keterampilan teknis dalam melaksanakan tugas sebagai manager sekolah untuk memperdayagunakan segala sumber yang tersedia untuk mencapai tujuan secara efektif dan efesien. (Atmodiwirio, 2002:107) Ukuran seberapa efisien dan efektifnya seorang manajer adalah seberapa baik dia menetapkan rencana dalam mencapai tujuan yang memadai, kemampuan memimpin secara efektif merupakan kunci keberhasilan organisasi. Kepala sekolah sebagai manajer pada jalur pendidikan formal dituntut memiliki kemampuan manajemen dalam menjalankan tugas dan tanggung jawabnya agar mampu mencapai tujuan proses belajar mengajar secara keseluruhan. Berdasarkan hasil penelitian kemampuan manajerial memiliki kontribusi yang lebih besar pengaruhnya terhadap efektivitas pengelolaan sekolah dibandingkan dengan variabel lainnya hal ini mengisyaratkan bahwa kecakapan yang dimiliki kepala sekolah dalam mengelola sekolah sangat berpengaruh terhadap keberlangsungan organisasi tersebut.

Menurut Wanardi (2002:91-92) peranan manajer ada tiga, yaitu:(1) Peran antar pribadi (Interpersonal Roles); peran ini memusatkan perhatian pada hubungan-hubungan antar perorangan, (2) Peran infomasional (Informational Roles); peran ini menyebabkan manajer menjadi fokus sentral untuk menerima dan mengirimkan informasi yang bersifat non-rutin, dan (3) Peran keputusan (Decisional Roles); setelah dikembangkan hubungan antar pribadi dan dikumpulkannya informasi, maka perlu adanya sebuah keputusan.

Menurut Hersey, dkk (1997:6-7) dalam rangka pelaksanaan tugas-tugas manjerial paling tidak diperlukan tiga macam bidang keterampilan, yaitu technical, human, dan conceptual" Robbin (2003:7) juga mengemukakan bahwa "Tugas manajerial paling ticlak diperlukan tiga macam bidang keterampilan yaitu : keterampilan konseptual, keterampilan manusiawi dan keterampilan teknis"Harsey (1997:6-7) membedakan tiga macam jenjang manager, yaitu Top Manager, Middle Manager dan Supervisory Manager. Untuk Top Manager keterampilan yang paling dominan adalah Human skill adapun technical skills sangat diperlukan manager tingkat supervisory.

Demikian pula peranan kepala sekolah sebagai manajer sangat memerlukan ketiga macam keterampilan tersebut. Dari ketiga bidang 
keterampilan tersebut, human skill merupakan keterampilan yang memerlukan perhatian khusus dari para kepala sekolah, sebab melalui human skills seorang kepala sekolah dapat memahami isi hati, sikap dan motif orang lain, mengapa orang lain tersebut berkata dan berperilaku. Agar seorang kepala sekolah secara efektif dapat melaksanakan fungsinya sebagai manajer, kepala sekolah harus dan mampu mewujudkan ke dalam tindakan atau perilakau nilai-nilai yang terkandung di dalam ketiga keterarnpilan tersebut, yaitu:(1) Conceptual skill yang meliputi kemampuan analisis, kemampuan berpikir, rasional, kemampuan dalam berbagai macam konsepsi, kemampuan dalam menganalisis berbagai kejadian, kemampuan dalam memahami berbagai kecenderungan, kemampuan dalam mengantisipasi perintah dan kemampuan mengenali macam-macam kesempatan dan problem-problem sosial, (2) Technical Skill yang meliputi kemampuan dalam menguasai pengetahuan tentang metode, proses, prosedur dan teknik untuk melaksanakan kegiatan khusus dan kemampuan untuk memanfaatkan serta mendayagunakan sarana, peralatan yang diperlukan dalam mendukung kegiatan yang bersifat khusus, dan (3) Human skill meliputi kemampuan untuk memahami perilaku manusia dan proses kerja sama, kemampuan untuk memahami isi hati, sikap dan motif orang lain, mengapa mereka berkata dan berperilaku, kemampuan untuk berkomunikasi secara jelas dan efektif, kemampuan menciptakan kerja sama yang efektif, kooperatif, praktis dan diplomatik dan kemampuan dalam berperilaku yang dapat diterima (Wahjosumidjo,2003:101-102).

Pendapat lain mengemukakan bahwa hasil kegiatan manajerial mengidentifikasikan adanya landasan utama fungsi-fungsi manajemen yaitu planing and decision making, organizing, for effective performance, leading motivating, and controlling performance." (Lingieneeker,1981:32-35). Seorang kepala sekolah dikatakan berhasil dalam memimpin jika ia memahami keberadaan sekolah sebagai organisasi yang komplek dan unik, serta mampu melaksanakan peranannya sebagai sesorang yang diberi tanggung jawab untuk memimpin sekolah. Tugas kepala sekolah sebagai manajer harus mampu melakukan pengorganisasian secara baik dan tepat. Lembaga pendidikan mempunyai sumber daya yang cukup besar mulai sumber daya manusia yang terdiri dari guru, karyawan dan siswa, sumber daya keuangan hingga fisik dari gedung serta sarana dan prasarana yang dimiliki. Kepala sekolah harus mampu menggunakan dan memanfaatkan sumber daya yang tersedia dengan sebaik-baiknya sehingga seni mengelola sumber daya menjadi keterampilan yang tidak bisa ditinggalkan. Dari uraian tersebut jelas bahwa kemampuan manajerial sangat berpengaruh terhadap efektivitas pengelolaan sekolah. Efektivitas pengelolaan sekolah tercipta apabila pemimpinnya memiliki kecakapan dalam mengelola organisasi dan sumberdaya yang ada dalam mencapai tujuan organisasi.

\section{KESIMPULAN DAN SARAN}

\section{Kesimpulan}

Terdapat pengaruh yang signifikan dan positif antara kemampuan manajerial terhadap efektivitas pengelolaan sekolah. Kontribusi kemampuan manajerial terhadap variabel efektivitas pengelolaan sekolah adalah sebesar $60,6 \%$ varian efektivitas pengelolaan sekolah dapat dipengaruhi oleh variabel kemampuan manajerial dan sisanya dipengaruhi variabel lain yang tidak diteliti dalam penelitian ini. Berdasarkan hasil tersebut maka dapat dikatakan bahwa peningkatan efektivitas pengelolaan dapat dilakukan dengan penguatan kemampuan manajerial kepala sekolah.

\section{Saran}

Kemampuan manajerial kompensasi mempunyai pengaruh signifikan terhadap efektivitas pengelolaan sekolah. Oleh karena itu resiko adanya penurunan efektivitas pengelolaan sekolah yang disebabkan oleh faktor kemampuan manajerial harus ditanggulangi. Hasil penelitian ini merekomendasikan kepada Dinas Pendidikan dan Kebudayaan di Kabupaten Kutai Kartanegara agar di masa yang akan datang memperbanyak pelatihan-pelatihan maupun workshop tentang kepemimpinanmenjadi prioritas mulai dari besarannya dan penyalurannya. Dengan upayaupaya yang serius, maka diharapkan untuk masa yang akan datang peranan kemampuan manajerial akan tetap memberikan kontribusi dalam meningkatkan efektivitas pengelolaan sekolah. 
Peneliti lain yang akan meneliti faktor yang berhubungan dengan efektivitas pengelolaan sekolah, aspek-aspek lain yang selama ini belum diteliti perlu diteliti pengaruhnya terhadap efektivitas pengelolaan sekolah. Aspek-aspek tersebut misalnya kesejahteraan, budaya kerja, hubungan antara personal, kreativitas, supervisi, dan lain-lain. Dengan penelitian aspek-aspek lain maka nantinya dapat menambah referensi seberapa jauh dan aspek-aspek apa saja yang dapat mempengaruhi efektivitas pengelolaan sekolah.

\section{DAFTAR RUJUKAN}

Atmodiwirio, S. 2002. Manajemen Pelatihan. Jakarta: Ardadizya Jaya.

Azwar, S. 2003. Reliabilitas dan Validitas. Yogyakarta: Pustaka Pelajar.

Hersey, P, et.al. 1997. Managemen of Organisation Behavior \& Utilizing Human Recaurses. Third Editsun. Prentice-Hall, Inch, Englewood lifts. New Jersey 07832.

Indonesia, Media. 2016. Hanya 10\% kepsek yang tesertifikasi. http://mediaindonesia.com/news/ read/42849/hanya-10-kepsek-yang-tesertifikasi. Diakses tanggal 01 Nopember 2016.

Lingieneeker, et.al. 1981. Management, 5 edition. Published by Charles E. merril Publishing Co., A Bell \& Howell Company, Columbus, Ohio 43216.
Peraturan Menteri Pendidikan Nasional Nomor 19 tahun 2007 tentang Standar Pengelolaan Pendidikan oleh Satuan Pendidikan Dasar dan Menengah.

Peraturan Pemerintah Nomor 32 Tahun 2013 Tentang Perubahan Atas Peraturan Pemerintah Nomor 19 Tahun 2005.

Peraturan Pemerintah Republik Indonesia Nomor 19 tahun 2005 tentang Standar Nasional Pendidikan.

Mustiningsih. 2015. Masalah Implementasi Manajemen Berbasis Sekolah di Sekolah Dasar.http://ap.fip.um.ac.id/Jurnal Manajemen Pendidikan Universitas Negeri Malang. Vol. 24, No. 6, September 2015: 498-505. Diakses 10 Nopember 2016.

Robbins,S.P. 2003.PerilakuOrganisasi. Jakarta:Gramedia.

Scheerens, J. 2003. Peningkatan mutu sekolah. Alih bahasa oleh Abas Al-Jauhari. Ciputat: PT. Logos Wacana Ilmu.

Siagian, S.P. 2002.Kepemimpinan Organisasi dan Perilaku Administrasi, Jakarta: Penerbit Gunung Agung.

Sugiyono. 2013.Metode Penelitian Pendidikan: Pendekatan Kuantitatif, Kualitatif, dan R\&D. Bandung: Alfaberta.

Undang-Undang Republik Indonesia Nomor 23 tahun 2014 tentang Pemerintahan Daerah.

Wahjosumidjo. 2003.KepemimpinanKepalaSekolah,J akarta:PT.RajaGrafindoPersada.

Wanardi. 2002.Sejarah Perkembangan Pemikiran Dalam Bidang Manajemen, Bandung: Mundur Maju. 